\title{
The Mediterranean Diet and the Increasing Demand of the Olive Oil Sector: Shifts and Environmental Consequences
}

\author{
Bruno Neves ${ }^{1}$, Iva Miranda Pires ${ }^{1}$ \\ ${ }^{1}$ Universidade Nova de Lisboa, Lisbon, Portugal \\ Received: 29 September 2017/Accepted: 13 May 2018
}

\begin{abstract}
Mediterranean countries play a crucial role as olive oil producers and consumers compared to other world regions. In particular, the Northern Mediterranean countries, where Spain, Italy, Greece and Portugal alone represent $68 \%$ of the world's olive oil production and $43 \%$ of world consumption. Nevertheless, aspects such as communication with emphasis on the benefits of the Mediterranean diet - which is a distinctive characteristic of the Mediterranean culture and identity and where olive oil plays an important role - the Slow Food Movement, the International Olive Council campaigns, and the successive Common Agricultural Policies, have triggered production, trade and consumption around the world. Such increases and stimuli brought and are still bringing changes to the olive oil sector such as a shifting tendency in production modes as well as modernization of the sector and new plantations, in response to consumers' increasing demand. But these shifts are creating a paradoxical situation in the sense that the promotion of a healthier diet is having a perverse environmental effect as the production of olive oil is shifting to more intensive production systems and monoculture plantations which are changing landscapes and are referred to as environmentally harmful to the ecosystems. These issues are here debated and illustrated with case study examples, referring to the Mediterranean countries, particularly in the Iberian Peninsula.
\end{abstract}

JEL classification: Q18

Key words: Agricultural Policies, Environment, Mediterranean Diet, Olive Oil

\section{Introduction}

The Mediterranean Diet plays an important role in Mediterranean societies given the large scope of its meaning and what it represents. Its relevance led to a joint application from multiple Mediterranean countries, comprising Cyprus, Croatia, Spain, Greece, Italy, Morocco and Portugal, to submit a nomination to the United Nations Educational, Scientific and Cultural Organization (UNESCO) for the recognition of the Mediterranean Diet as Intangible Cultural Heritage of Humanity.

As it can be read on the Nomination File No. 00884 from UNESCO (2013b), the Mediterranean Diet is a way of life, involving a set of skills, knowledge, rituals, symbols 
and traditions, and it respects crops, harvesting, picking, fishing, animal husbandry, conservation, processing, cooking and, foremost, the act of sharing and eating the traditional cuisine together at a table, where knowledge floats from generation to generation. It encompasses a strong social sense transposed to the cultural spaces, festivals and other celebrations associated to the Mediterranean, emphasizing values of mutual recognition and respect, hospitality, neighborliness, conviviality, intergenerational transmission and intercultural dialogue.

The Mediterranean Diet was inscribed on the Representative List of the Intangible Cultural Heritage of Humanity, a decision that was made during the Eighth Session of the Intergovernmental Committee (8.COM) held in Baku, Azerbaijan, from Monday 2nd to Saturday 7th December 2013, and can be read on the "Decisions" document, released with all decisions taken at the 8.COM, namely the Decision 8.COM 8.10 concerning to the Mediterranean Diet (UNESCO 2013a, p. 36-37).

This recognition of the Mediterranean Diet by UNESCO highlighting the abovementioned aspects gives it a broader range and influence not only in the region itself but worldwide. The benefits of the Mediterranean Diet have also been recognized by other institutions such as the Food and Agriculture Organization (FAO) of the United Nations, the International Olive Council (IOC), and the European Union, amongst others.

If UNESCO recognized added value in the Mediterranean Diet through its set of skills, knowledge, practices and traditions, the FAO recognition was more concerned to its relevancy to greener economies and development in regions of small-scale tourism and agriculture. Such recognition was previously highlighted by FAO through the inclusion of the Mediterranean Diet in the group of the most sustainable diets in 2012 (Moro 2016), which is defined as "those diets with low environmental impacts which contribute to food and nutrition security and to a healthy life for present and future generations. Sustainable diets are protective and respectful of biodiversity and ecosystems, culturally acceptable, accessible, economically fair and affordable; nutritionally adequate, safe and healthy; while optimizing natural and human resources" (FAO 2010, p. 7).

Other institutions highlight food products associated to the Mediterranean Diet that may be referred to in groups, representing a pyramid of the optimal Mediterranean Diet or mentioned as a list (Huang, Sumpio 2008).

The IOC website has a webpage dedicated to the "Mediterranean Diet Pyramid" and the food products are presented by categories in a descending order of recommended quantity and frequency. The classification is presented as follows: (i) grains (bread, pasta, couscous and rice); (ii) fruits and vegetables (in-season products. Fruits eaten as dessert); (iii) legumes and nuts (chickpeas, lentils, haricot beans, pine kernels, almonds, hazelnuts, walnuts); (iv) olive oil and olives; (v) dairy products (cheese, yoghurt and other dairy products, although milk is not specially mentioned), and; (vi) fish (seen as first-class protein). On the top level of the pyramid, and therefore, the least advised food products, are red meat, sweets and pastries. Wine (preferably red) is advised to be consumed with moderation during meals and no more than two glasses per day (IOC nd). Out of the food products, regular physical activity is also recommended (Huang, Sumpio 2008, IOC nd).

In literature when food products related to Mediterranean Diet are mentioned, often health benefits are revealed, forming an inseparable association (Huang, Sumpio 2008, Pires, Neves 2013). In Moro (2016), Mediterranean Diet is described as a "healthy system of living and feeding" along with a list of food products similar to the above listed. Huang, Sumpio (2008) refer to the inhabitants of the involving regions surrounding the North and South of the Mediterranean Sea to have a longer life expectancy and lower risk of chronic diseases, in comparison with other world regions. Mediterranean Populations' diet and lifestyle are believed to have led to decreased rates of cancer, diabetes and heart diseases.

Independently of the scope of institutions or sources of information about Mediterranean Diet (e.g. cultural, social, environmental, health, and food products) in this paper we are focusing on olive oil, the fat (of choice) associated with the Mediterranean Diet.

The olive oil market is characterized by a period of considerable stability during the 1970s, a situation that would change in the following decades. In the 1980s, the olive oil sector registered a growth due to changes introduced in dietary patterns and increasing 
demand in non-producing countries, an answer that had to be given by producing countries. Despite the increasing and continued demand registered since the 1980s, it is the shifting to the 21st century that sets a breaking point in which olive oil shifted from being an expensive niche commodity to an everyday product. These changes became evident and acquired more visibility in Europe. Food stores started having more brands and varieties of olive oil than other cooking or edible oils, reducing their importance in the market (Neves, Pires 2013, Scheidel, Krausmann 2011).

The next section discusses how communication emphasizing the benefits of the Mediterranean Diet in general, and olive oil in particular, the Slow Food Movement and campaigns such as those being promoted by the IOC, and the successive Common Agricultural Policies (CAP) have been stimulating an increasing demand and subsequently changing the olive oil industry and its practices towards intensive and super-intensive modes of production in order to meet that demand. Then, in the following session, we discuss how those stimuli have been environmentally undermined and we illustrate those situations with Iberian Peninsula case study examples.

\section{Olive Oil Stimuli in a changing Industry}

\subsection{The International Olive Council campaigns}

Olive oil has been part of the populations' diets in the Mediterranean region for thousands of years (de Graaff et al. 2008), its advantages being well known, scientifically studied and proved. It has been presented as a healthy natural product that contributes to a more balanced diet, a fundamental good that contributes to a healthier lifestyle (Neves, Pires 2013, Pires, Neves 2013).

The marketing generated around olive oil would, in fact, take over the healthy tags linked to olive oil and supported by the benefits of the Mediterranean Diet. It followed the wine industry, presenting fine design of bottles and creative labels introducing gourmet versions for high-end segments, such as extra virgin olive oils (Pires, Neves 2013).

Founded in 1959, with the objective to support and promote the olive oil production, trade and consumption, the IOC saw its objective accomplished by emphasizing precisely the health benefits of olive oil. Back then the underlined health benefits were associated with anti-aging, cardiovascular diseases, pregnancy and obesity (Huang, Sumpio 2008, Scheidel, Krausmann 2011). With a total budget of approximately 10 million Euros, IOC was spending half of its budget in promoting olive oil worldwide (Scheidel, Krausmann 2011).

In 1986, the European Union started to support the IOC with an annual budget of five million Euros, that lasted until 2002 and was considerably reduced afterwards to half a million (Scheidel, Krausmann 2011).

\subsection{The European Union campaigns}

Even though the "partnership" between IOC and EU dates from 1986, the EU promotion campaigns started earlier. In 1981, the EU was starting olive oil promotional campaigns only in producing countries. The objective at that time was clear, to replace other edible oils, commonly designated as cheaper, in the market by olive oil. In 1991 the EU widened its campaigns to non-producing countries, and, as it was already mentioned, since 1986, the EU was co-funding the IOC promotional campaigns (Scheidel, Krausmann 2011). According to the same authors, it is estimated that the total amount spent in olive oil campaigns from 1985 to 2002 exceeded 150 million Euros.

Around this time, the campaigns started shifting their messages, indicating a change in objectives and ultimately the discourse around olive oil. The goal was no longer to replace other oils in the market but instead to promote olive oil as a healthy commodity in line with the Mediterranean Diet benefits discourse. Despite the scientific basis supporting these EU campaigns and highlighting the health benefits of olive oil, it was not consensual, and therefore, there were some critics around the motto of the campaigns (Scheidel, Krausmann 2011). 


\subsubsection{The Common Agricultural Policy (CAP) campaigns}

Within the CAP there were two periods worth mentioning: the 1998 CAP reform, initially set from 1998 to 2001, and extended until 2004, in which the EU was supporting products and producers through market-based policies, and at the same time, improving production systems and infrastructures through structural policies. In 2003, the EU introduced a PAC reform with the main objectives of encouraging productivity, market stabilization and protecting rural livelihoods (De Gennaro et al. 2012, de Graaff et al. 2011, Scheidel, Krausmann 2011, Stoate et al. 2009).

The first trend of market based policies was justified by the relevance of olive oil production and consumption in specified regions and was thus provided as aid to production and consumption. Along with it came price support and trade barriers imposed on third countries, avoiding cheap olive oil imports. As a result, the large amounts of aid provided by CAP led to an increase and intensification of the olive oil sector, being this aid proportional to the amount of olive oil produced. Production aid was initially set to last from 1998 until 2001, however, the Regulation Nr. 1513/2001 of the European Community extended it until 2004. With the end of the production aid, new mandatory environmental rules were introduced to agricultural practices. These changes reflected environmental concerns related to further intensification in production modes and it was expected that such measures would reduce the erosion rates that arose, a consequence of such reforms (European Commission 2003, de Graaff et al. 2010, Scheidel, Krausmann 2011, Stoate et al. 2009). The new policy was more concerned with qualitative aspects, such as product quality, food safety and environmental aspects rather than with the quantitative aspects inherent to previous policies (Costantini, Barbetti 2008, Türkekul et al. 2010).

The actual CAP (2014-2020) is raising some concerns due to the downward trend that has been occurring in the allocation of funds to the agricultural sector. In 2007, $50 \%$ of the EU budget was allocated to CAP, decreasing to $42 \%$ in 2013 , and to $35 \%$ of the total budget in 2020 (Mylonas 2015, p. 13). Nevertheless, CAP continues to be the largest segment of the EU total budget, allocating 408.31 billion Euros, through two main Pillars (First Pillar 308.73 billion Euros and Second Pillar 99.58 billion Euros in EU funds), during this CAP period. Pillar I provides 'Direct Payments' to farmers guaranteeing farm revenues stabilization and aiming to diminish inequalities in funds attribution among member states. Pillar II supports for long-term 'Rural Development', attempting to modernize the sector, becoming more competitive, maintaining quality and environmental concerns (European Commission 2013, 2016), aiming to more greener and sustainable agriculture, which was not yet achieved (Matthews 2013).

\subsection{The Slow Food Movement}

In Rome, Italy, in the 1990s, fast food restaurants began to gain a prominent place in the market. In response to the spread of fast food restaurants, a movement arose. The Slow Food Movement started by promoting healthy diets in which olive oil had an important role. This movement soon started to outgrowth convening an international extent and becoming a philosophy of life, encouraging local and sustainable agri-food systems and local food traditions, adjusting food in view of its cultural, social, economic, geographical and environmental contexts through alternative food networks (Ferreira 2009, Goodman, Goodman 2007, Neves et al. 2013). Values that are consistent with the principles of the Mediterranean Diet.

\section{The Olive Oil Market}

Edaphoclimatic characteristics confine world olive oil production into two zones, between 30 and 45 degrees latitude from both the North and the South hemispheres. Nevertheless, olive oil is produced outside these regions, and production is rising (Pires, Neves 2013).

In the last 25 years under analysis the world production of olive oil has more than doubled (IOC 2015d). The Mediterranean region encompasses the core of the olive oil production (Table 1), which plays an important role in social, economic and environmental terms (Avraamides, Fatta 2008, Muktadirul Bari Chowdhury et al. 2013, Salomone, 
Table 1: Olive oil production

\begin{tabular}{lrrrr}
\hline Olive oil & \multicolumn{2}{c}{$2015 / 16$} & \multicolumn{2}{c}{$1990 / 91$} \\
Production & Tons & $\mathrm{P}(\%)$ & Tons & $\mathrm{P}(\%)$ \\
\hline Mediterranean countries & $2,861,000$ & 95.73 & $1,400,700$ & 96.40 \\
Europe & $2,060,500$ & 68.95 & 999,200 & 68.77 \\
European Union & $2,049,500$ & 68.58 & 994,000 & 68.41 \\
Africa & 601,500 & 20.13 & 307,500 & 21.16 \\
Middle East & 237,500 & 7.95 & 102,500 & 7.05 \\
South America & 42,500 & 1.42 & 10,500 & 0.72 \\
Oceania & 18,000 & 0.60 & $\mathrm{~N} / \mathrm{D}$ & $\mathrm{N} / \mathrm{D}$ \\
North America & 14,000 & 0.47 & 1,000 & 0.07 \\
Other producing countries & 14,500 & 0.49 & 32,000 & 2.20 \\
World production & $2,988,500$ & 100.00 & $1,453,000$ & 100.00 \\
\hline
\end{tabular}

Source: IOC (2015b,d)

Ioppolo 2012, Türkekul et al. 2010). This region alone produces $95.7 \%(2,861,000$ of $2,988,500$ tons) of the worlds' olive oil, a share that was slightly reduced with the expansion of the production market. In 1990/91, Mediterranean countries were producing 1,400,700 out of 1,453,000 tons, corresponding to $96.4 \%$ of total production (IOC 2015d). European Union countries in the North Mediterranean region are the largest producers worldwide with nearly 3/4 of total production (European Commission 2003, Türkekul et al. 2010), a slightly reduced share, given the emergence of other producing countries (Neves, Pires 2013). Currently, European Union is responsible for nearly $69 \%$ (2,049,500 tons) of the olive oil production (IOC 2015b).

Spain is the country that produces the most worldwide and since it joined the EU together with Portugal in 1986, olive oil production has experienced a substantial growth. CAP reforms have led to an increase in new plantations and a rise in productivity. This was accomplished by improving growing techniques such as replacing old trees with new ones as well as increasing the number of trees per area (intensive modes of production) and by introducing irrigation to the olive groves production system (Türkekul et al. 2010).

In 1990/91, Spain was the worlds' most productive country with 639,400 tons, $44 \%$ of total production (1,453,000 tons). Today, Spain is still the leading producer and has more than doubled its production. With 1,300,000 tons, Spain produces today $43.5 \%$ of the worlds' olive oil, a total of 2,988,500 tons (IOC 2015b,d).

Portugal has benefited from the same CAP-EU reforms as Spain, which allowed it to modernize and expand the olive sector, and similarly introducing intensive and irrigated modes of production (INE 2010, Neves et al. 2013, Pires, Neves 2013). Portugal is today the eighth largest producing country of olive oil worldwide and occupies the fourth place within the EU with 82,000 tons. Portugal increased its production more than four times (20,000 tons) since 1990/91 (IOC 2015b,d).

Consumption rose significantly from 1990/91 (1,666,500 tons) until the present time $(2,989,000$ tons $)$ and, although it mostly occurred in producing countries, it is more widespread than production (Table 2; Figure 1). The Mediterranean region is responsible for about $2 / 3$ of the total consumption of olive oil. In 2015/16, in the Mediterranean region, consumption was expected to represent $65.8 \%$ of the world's consumption, which is $1,966,800$ of a total of $2,989,000$ tons. A much different share compared to 1990/91. At that time $86.7 \%(1,445,100$ tons) were consumed in the region (IOC 2015a,c).

The EU alone was responsible for about $73 \%$ of total consumption in 1990/91 (IOC 2015a,c), a share that is becoming lower with the current market's tendency (Figure 1). In $2007 / 08$, slightly more than $2 / 3$ of the total share of olive oil was consumed in the EU (Türkekul et al. 2010). Today it represents just 54\% (1,615,000 tons) in relation to total consumption (IOC 2015c). Although the rates are presently lower due to the spreading of markets, consumption is much higher and the general tendency points to a continuous growth in consumption (IOC 2015a,c).

Despite its leading role as world producer, Spain is not the country that consumes the 
Table 2: Olive oil consumption

\begin{tabular}{lrrrr}
\hline Olive oil & \multicolumn{2}{c}{$2015 / 16$} & \multicolumn{2}{c}{$1990 / 91$} \\
Consumption & Tons & $\mathrm{P}(\%)$ & Tons & $\mathrm{P}(\%)$ \\
\hline Mediterranean countries & $1,966,800$ & 65.80 & $1,445,100$ & 86.71 \\
Europe & $1,645,500$ & 55.05 & $1,223,400$ & 73.41 \\
European Union & $1,615,000$ & 54.03 & $1,214,500$ & 72.88 \\
Africa & 436,000 & 14.59 & 175,500 & 10.53 \\
Middle East & 242,000 & 8.10 & 87,000 & 5.22 \\
North America & 346,500 & 11.59 & 98,000 & 5.88 \\
Asia & 120,500 & 4.03 & 9,000 & 0.54 \\
South America & 94,500 & 3.16 & 21,500 & 1.29 \\
Oceania & 37,500 & 1.25 & 13,500 & 0.81 \\
Other prod. countries & 11,500 & 0.38 & 21,000 & 1.26 \\
Other non prod. countries & 55,000 & 1.84 & 21,000 & 1.26 \\
World consumption & $2,989,000$ & 100.00 & $1,666,500$ & 100.00 \\
\hline Source: (IOC 2015a,c) & & & &
\end{tabular}

most. Italy holds the first place as olive oil consumer for decades. In 1990/91, in Italy, 540,000 tons (32.4\%) were being consumed, followed by Spain with 394,100 tons (23.7\%). Today, Italy is still the largest consumer worldwide and it is still followed by the world leading producer, Spain, with 580,800 tons (19.4\%) and 490,000 tons (16.4\%), respectively, of the worlds' consumption. In 1990/91, Portugal was in tenth place consuming 27,000 tons and ranked fifth amongst the EU countries. Today, consumption more than doubled in the country. The 74,000 tons being consumed at present time contributed to the country's rise to the ninth place as world consumer, maintaining the fifth place amongst the EU countries (IOC 2015a,c).

Outside the Mediterranean region, new markets are emerging. The USA is the most prominent while Australia, Brazil, Canada, China, Japan and Russia are also notable markets (European Commission 2012, Salomone, Ioppolo 2012, Türkekul et al. 2010). It is precisely non-producing countries that are consolidating their position in the market as olive oil consumers, explaining the increase in production. Therefore, non-European producing countries in the Mediterranean basin are reinforcing their market share, in some cases, by doubling production in the last 25 years, taking advantage of the stimuli provided by the olive oil sector (IOC 2015d, Mylonas 2015). Despite this, the EU is still responsible for about $2 / 3$ of the world exports and wants to secure that position (Rossi 2017), being the olive oil sector one of the most privileged by CAP, compared to other products such as wine, fruits or vegetables (Mili et al. 2017, Ozden, Dios-Palomares 2016). In 2010/11, exports to third countries reached 447,000 tons, with Spain and Italy contributing the majority share, selling 225,000 and 160,000 tons respectively (European Commission 2012). At the same time, the actual CAP is raising concerns and negative consequences may arise due to expected cuts in subsidies until 2020 (Mylonas 2015, p. 9).

\section{Environmental Consequences}

While traditional olive groves were once characterized by natural value agricultural systems, recent changes due to the introduction of intensive modes of production have led to negative environmental consequences (De Gennaro et al. 2012, de Graaff et al. 2011, Muktadirul Bari Chowdhury et al. 2013, Ozden, Dios-Palomares 2016).

In Neves, Pires (2013) these consequences are systematized as follows: (i) loss of diversity and landscape modifications; (ii) soil erosion, and; (iii) water consumption and contamination.

Olive trees are highly adaptable to climate in the Mediterranean region (Scheidel, Krausmann 2011) allowing its cultivation in marginal soils, with low fertility (Huang, Sumpio 2008) or in terraces using very low quantities of fertilizers, herbicides and pesticides, characteristic of the traditional olive groves' system (de Graaff et al. 2011, 

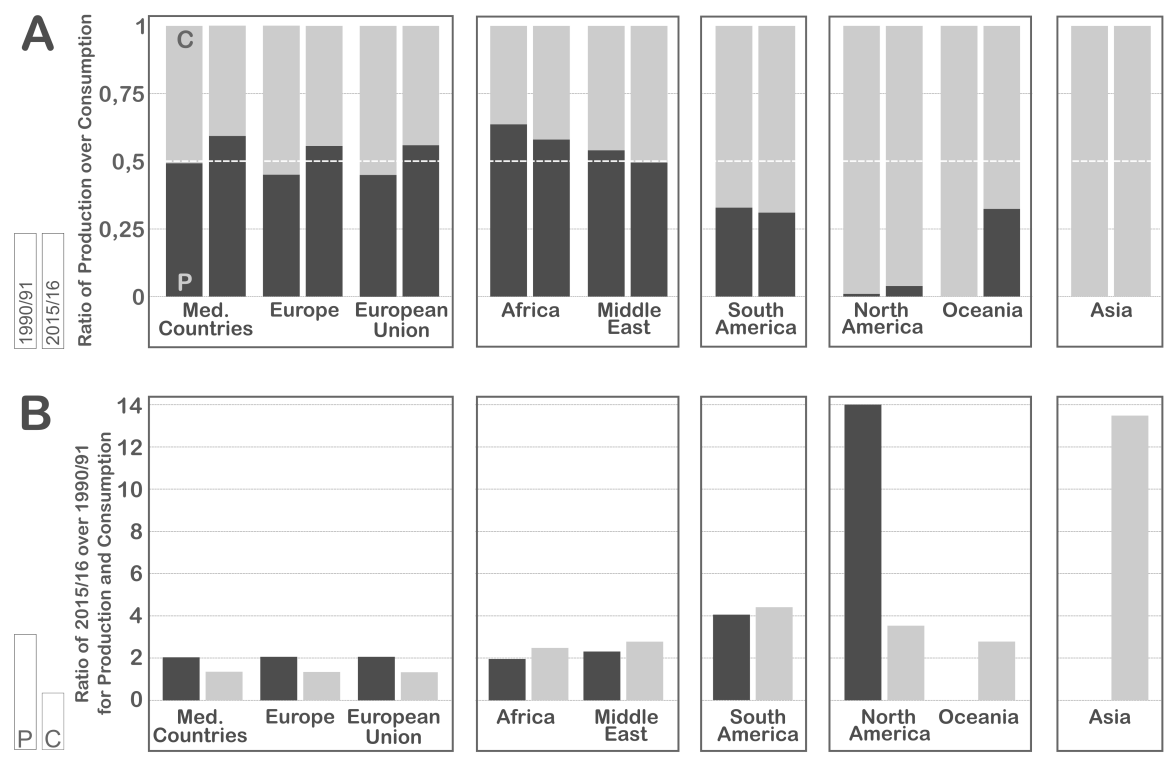

Notes: Notes: $\mathrm{P}=$ Production; $\mathrm{C}=$ Consumption. Countries in the IOC 2015a,b,c,d were merged by 'region'. Regions were grouped in five blocks according to the following criteria (from left to right): (1) production grew more than consumption; (2) consumption grew more than production; (3) identical production and consumption growth; (4) emerging producing regions that do not yet meet consumers' demand; (5) purely consumer regions.

Figure 1: Dynamics of production and consumption by world regions. (A) Relative weight of production over consumption in 1990/91 and 2015/16 and (B) relative growth in 2015/16 over 1990/91 of production and consumption

Neves, Pires 2013) where spacing between trees (an average of 100 trees per hectare) allows a second crop or pastoralism to be part of a biodiverse landscape (Avraamides, Fatta 2008, European Commission 2012, Ferreira 2010).

Biodiversity loss is highly associated with any crop intensification which adds additional pressures to the environment (Metzidakis et al. 2008). These issues were added to olive groves by shifting farming practices to more intensive modes of production (which can exceed even 2,000 trees per hectare), leading to a transformed landscape with shortened biodiversity (Costantini, Barbetti 2008, Scheidel, Krausmann 2011, Weissteiner et al. 2011).

Intensive monocultures are equally associated with erosion (de Graaff et al. 2011, Salomone, Ioppolo 2012), and according to Beaufoy (2001), the shifting of olive groves to more intensive modes of production not only contributes largely to erosion but it can lead to desertification. Contrary to traditional olive groves that, normally, are not irrigated, intensive and super-intensive olive groves are irrigated. This brought about significant changes in water consumption since these practices are very water-intensive (Avraamides, Fatta 2008, de Graaff et al. 2011).

Environmental problems are not only related to water consumption but also to the high inputs of fertilizers and herbicides used in these intensive modes of production which, in turn, are associated with air, soil and water bodies' contamination (Neves, Pires 2013, Roig et al. 2006, Stroosnijder et al. 2008) and create an encouraging environment to pests and diseases resulting from the excessive use of water (Metzidakis et al. 2008). Rivers in the Mediterranean region have been subject to uncontrolled discharges of olive mill waste (Roig et al. 2006). Dumping olive mill waste was a common practice until the end of the last century, despite its prohibition in the early 1980s. To overcome these issues, new uses have been given to olive mill wastes, such as fertilizer or for the production of bioenergy (Muktadirul Bari Chowdhury et al. 2013, Scheidel, Krausmann 2011). Olive oil extraction systems have also been subject to technological changes. Presently, most olive mills are already equipped with the so-called two-phase olive mill waste. It is more environmentally friendly and needs considerably fewer amounts of water in the olive oil extraction process 
(Roig et al. 2006). This technology is now being used in several Mediterranean countries. Spain, which for decades has had serious environmental problems related to olive mill waste, have now $75 \%$ of its mills equipped with such technology (IOC 2012).

\section{The Iberian Peninsula and reported environmental problems related to the olive oil sector}

Olive oil production in its intensive and super-intensive modes of production are related to high rates of erosion in low fertility soils that are now losing biodiversity and introducing great landscape transformations (Vanwalleghem et al. 2010).

Andalusia, Spain, is the most productive region in the world concerning olive groves (Mili et al. 2017). Between 2000 and 2003, the region produced on average $39 \%$ of the world's olive oil and $24 \%$ of table olives (Gómez et al. 2009).

Today, the Andalusian autonomous community alone, is responsible for $75 \%$ of the Spanish olive oil production, which is about $35 \%$ of the global production. Despite the region shifting to more sustainable olive oil farming production modes, especially integrated and organic (Mili et al. 2017), it is still facing major problems related to soil loss (Scheidel, Krausmann 2011). In a 2002 study carried out in the Andalusian region, reported topsoil losses in olive groves were on average around 62 tons per hectare/year. Although, in certain areas of the region topsoil losses reached 92 tons per hectare/year. The lowest rate of topsoil losses was estimated at 36 tons per hectare/year. Such rates are considered to be very high compared to soil regeneration rates presented for the region, which vary from one to 12 tons per hectare/year (Scheidel, Krausmann 2011). This issue brought major concerns to the Spanish local government that resulted in the implementation of the National and Andalusian Action Plan against Desertification, meant for the application of good farming practices (Neves, Pires 2013).

In order to better understand the results of the study mentioned above, one must return to the beginning of the 1990s. The region of Andalusia at the beginning of the 1990s was facing periods of droughts and, at the same time, the EU was providing incentives through CAP to increase yields. These constraints and opportunities led to the development of Research and Development programs in a joint initiative from the Andalusian board and private olive producers in 1992. The outcome was the development of a drip irrigation and fertilizer (fertirrigation) system. This system irrigates and fertilizes according to the seasonal needs of the crop. Such technological development is responsible for the increase in productivity and the expansion and intensification (raising the number of trees per hectare) of the olive sector not only in Andalusia but throughout Spain (Scheidel, Krausmann 2011, Vanwalleghem et al. 2010).

Presently, erosion and desertification issues associated to crops' intensification, affect not only the Iberian Peninsula countries but also other Mediterranean countries, namely Greece and Italy (Costantini, Barbetti 2008, DGOTDU 2006, Gómez et al. 2009, Roig et al. 2006). Olive groves' intensive modes of production are being referred to as the most problematic crops concerning these issues (Beaufoy 2001, Neves, Pires 2013, Vanwalleghem et al. 2010).

These environmental problems highlighted an emergent need for solutions. Spain, the world's largest producer, has again and somehow succeeded to properly manage the problems here mentioned. One issue relates to the fact that Spain had exceeded quotas for olive trees and olive oil production, a problem that found an easy and favorable solution among the cross-border regions with the Portuguese territory, namely from the regions of Andalusia and Extremadura. Because Spain had exceeded quotas, the EU was financing the removal of olive trees. At the same time in Portugal, EU was funding the plantation of olive trees. That was done by a considerable number of Spanish olive oil producers. The compensations from removing olive trees from a certain area with exceeded quotas gave them the income necessary to invest in farms in Portugal to plant olive trees and be remunerated for an activity that they are very familiar with. These investors highlight the fact of existing available land and water, particularly in the Alentejo region. A region with high water availability since the construction of the Alqueva dam in 2002, and particularly since it reached its maximum level in 2010. Besides, water, land as well as 
labor are mentioned to be of lower cost in the Portuguese region comparatively to Spain. These are considered attractive and boosted investment in a time of repealing constraints due to the cross-border situation (Pires, Neves 2013).

By having the biggest artificial lake in Europe, with $250 \mathrm{Sq} . \mathrm{km}$, the Alqueva dam made it possible for the region of Alentejo to expand and transit from traditional to irrigated intensive and super-intensive modes of production. The transition began in the late 1990s, and with the Alqueva irrigation perimeter completely infrastructured and operational today, the olive groves' area is expected to double, and production to significantly increase. Investment is also expected to increase from Andalusia, where water and land resources are pointed as the main reasons (Pires, Neves 2013).

The Alentejo region holds $51 \%$ (173,392 hectares in 2011) of the total olive production area, with more than half of the national olive oil being produced here due to the high productivity rates $(1,873 \mathrm{~kg}$ per hectare), $24 \%$ higher than the national average (Neves et al. 2013). Also, note that this region is the second at the EU level with the largest holdings, only surpassed by the Andalusian region, with an average of 7.2 and 8 hectares per holding respectively (European Commission 2012).

\section{Discussion and Conclusions}

The values associated with the Mediterranean Diet led to its inclusion to the Representative List of the Intangible Cultural Heritage of Humanity. The Mediterranean Diet is, in fact, a way of life with knowledge, traditions, and a remarkable social sense, amongst other values and traditions, visible in many aspects of everyday life of Mediterranean cultures. But this recognition had a "perverse" impact in the sense that the valuation of olive oil, as one of the components of this diet, led to an unprecedented increase in demand in the last decades and, consequently, to its appreciation in the market. This appreciation has stimulated an increased production that was mainly accomplished through agriculture intensification.

The transition from a traditional production mode to intensive and super-intensive modes has altered the landscapes of the Mediterranean olive groves, namely in the Alentejo and Andalusia regions, introducing monotony (large extensions of kilometers only of olive groves) where before existed biodiversity and, above all, having negative environmental impacts in the medium and long terms. Therefore, olive oil should not be reduced to a commodity that is part of a list of consumer products, distinctive of the Mediterranean Diet, which presently is being produced in such a way that few or none meets the values or meaning emphasized by UNESCO.

The same way, the FAO's recognition of the Mediterranean Diet as one of the most sustainable diets can be used to promote olive oil. First of all, it refers to sustainability. As it can be read on their definition, a sustainable diet with low environmental impacts, contributing to a greener economy and respectful of biodiversity. Foremost, olive oil production is not restricted to intensive and super-intensive modes of production, even though, that is the current tendency, which at the same time ends up marginalizing small producers with no ability to compete in the market.

Such tendency benefits from the most recent achievements by FAO and UNESCO based on the Mediterranean Diet, but also from all the previous mentioned campaigns by IOC and EU (namely through the successive CAP) that led to significant changes, reflecting a valorization of olive oil especially in the world market, and raising its demand. A rise that has stimulated production intensification, generally in Northern Mediterranean countries. The intensification in production modes was followed by its mechanization, irrigation and increase of farms' dimensions. Consequently, in the 25 years in analysis, olive oil production has doubled and expanded worldwide and in the Mediterranean region in particular.

Again, one must remind that the current modes of olive oil production are being challenged considering its sustainability. This is particularly accurate in the Iberian Peninsula countries where environmental issues have been here stated and debated. In addition to that, the CAP aims to reduce the direct support to olive oil production, increasing the challenges for the sector. 


\section{Acknowledgement}

The article was made with the support of CICS.NOVA - Interdisciplinary Centre of Social Sciences of the Universidade Nova de Lisboa, UID/SOC/04647/2 013, with the financial support of FCT/MCTES through National funds.

\section{References}

Avraamides M, Fatta D (2008) Resource consumption and emissions from olive oil production: A life cycle inventory case study in Cyprus. Journal of Cleaner Production 16[7]: 781-884. CrossRef.

Beaufoy G (2001) EU policies for olive farming, unsustainable on all counts. WWF Europe and BirdLife International

Costantini EAC, Barbetti R (2008) Environmental and visual impact analysis of viticulture and olive tree cultivation in the province of Siena (Italy). European Journal of Agronomy 28[3]: 412-426. CrossRef.

De Gennaro B, Notarnicola B, Roselli L, Tassielli G (2012) Innovative olive-growing models: An environmental and economic assessment. Working towards a more sustainable agrifood industry: Main findings from the Food LCA 2010 conference in Bari, Italy, 28

de Graaff J, Duarte F, Fleskens L, de Figueiredo T (2010) The future of olive groves on sloping land and ex-ante assessment of cross compliance for erosion control. Land Use Policy 27[1]: 33-41. CrossRef.

de Graaff J, Duran Zuazo VH, Jones N, Fleskens L (2008) Olive production systems on sloping land: Prospects and scenarios. A Sustainable Future for Olive Production on Sloping Land 89[2]: 129-139

de Graaff J, Kessler A, Duarte F (2011) Financial consequences of cross-compliance and flat-rate-per-ha subsidies: The case of olive farmers on sloping land. Land Use Policy 28[2]: 388-394. CrossRef.

DGOTDU - Direcção-Geral do Ordenamento do Território e Desenvolvimento Urbano (2006) Combate à Desertificação: Orientações para os Planos Regionais de Ordenamento do Território. Direcção-Geral do Ordenamento do Território e Desenvolvimento Urbano, Lisbon, Portugal

European Commission (2003) The olive oil sector in the European Union. European Commission, Agriculture

European Commission (2012) Economic analysis of the olive sector. European Commission, Agriculture and Rural Development

European Commission (2013) Overview of CAP reform 2014-2020 (agricultural policy perspectives brief no. 5). European Commission, Agriculture and Rural Development

European Commission (2016) CAP in your country. European Commission, Agriculture and Rural Development

FAO - Food and Agriculture Organization (2010) Sustainable diets and biodiversity. Directions and solutions for policy, research and action. Food and Agriculture Organization of the United Nations, Rome, Italy. CrossRef.

Ferreira A (2009) The slow food movement. Master Thesis. Faculdade de Ciências da Nutrição e Alimentação, Universidade do Porto, Porto, Portugal

Ferreira D (2010) O olival em modo de produção biológico: Custos e Rentabilidade na região de Moura, Alentejo. Master Thesis. Instituto Superior de Agronomia, Universidade Técnica de Lisboa, Lisbon, Portugal 
Gómez JA, Sobrinho T, Giráldez J, E F (2009) Soil management effects on runoff, erosion and soil properties in an olive grove of Southern Spain. Soil and Tillage Research 102[1]: 5-13. CrossRef.

Goodman D, Goodman M (2007) Alternative food networks. In: Thrift N, Kitchin R (eds), International Encyclopedia of Human Geography, Volume 4. Elsevier, Amsterdam, $208-220$

Huang C, Sumpio B (2008) Olive oil, the Mediterranean diet, and cardiovascular health. Journal of the American College of Surgeons 207[3]: 407-416. CrossRef.

INE - Instituto Nacional de Estatística (2010) O que mudou na agricultura portuguesa nos últimos dez anos. Recenseamento Agrícola 2009. Dados Preliminares. Instituto Nacional de Estatística, Lisbon, Portugal

IOC - International Olive Council (2012) Policies - Spain. International Olive Council. Retrieved from http://www.internationaloliveoil.org/estaticos/view/136-country-profiles

IOC - International Olive Council (2015a) Olive oils - EU Consumption. International Olive Council. Retrieved from http://www.internationaloliveoil.org/estaticos/view/131world-olive-oil-figures

IOC - International Olive Council (2015b) Olive oils - EU Production. International Olive Council. Retrieved from http://www.internationaloliveoil.org/estaticos/view/131world-olive-oil-figures

IOC - International Olive Council (2015c) Olive oils - World Consumption. International Olive Council. Retrieved from http://www.internationaloliveoil.org/estaticos/view/132world-table-olive-figures

IOC - International Olive Council (2015d) Olive oils - World Production. International Olive Council. Retrieved from http://www.internationaloliveoil.org/estaticos/view/132world-table-olive-figures

IOC - International Olive Council (n.d.) Mediterranean diet pyramid. International Olive Council. Retrieved from http://www.internationaloliveoil.org/estaticos/view/87mediterranean-diet-pyramid

Matthews A (2013) Greening agricultural payments in the EU's common agricultural policy. Bio-Based and Applied Economics Journal 2[1]: 27

Metzidakis I, Martinez-Vilela A, Castro Nieto G, Basso B (2008) Intensive olive orchards on sloping land: Good water and pest management are essential. A Sustainable Future for Olive Production on Sloping Land 89[2]: 120-128

Mili S, Judez L, De Andres R (2017) Investigating the impacts of EU CAP reform 2014-20 and developments in sustainable olive farming systems. New Medit 16 [3]: 2-10

Moro E (2016) The Mediterranean diet from Ancel Keys to the UNESCO cultural heritage. A pattern of sustainable development between myth and reality. 2nd international symposium 'New Metropolitan Perspectives' - strategic planning, spatial planning, economic programs and decision support tools, through the implementation of Horizon/Europe2020. ISTH2020, Reggio Calabria (Italy), 18-20 May 2016, 223, 655-661

Muktadirul Bari Chowdhury AKM, Akratos CS, Vayenas DV, Pavlou S (2013) Olive mill waste composting: A review. International Biodeterioration 8 Biodegradation 85: 108-119

Mylonas P (2015) Olive oil: Establishing the Greek brand (sectoral report). National Bank of Greece, economic analysis department

Neves B, Pires IM (2013) The impact of agricultural policies and growing investment in olive sector in the Alentejo region. Políticas de Base e Recuperação Económica. Universidade do Minho, Braga, Portugal 
Neves B, Pires IM, Roxo MJ (2013) Culturas intensivas e superintensivas e a susceptibilidade à Desertificação: o caso do olival no Alentejo. In: Correia T, Henriques V, Julião R (eds), Geografia: Espaço, Natureza, Sociedade e Ciência. Associação Portuguesa de Geógrafos, Évora, Portugal, 44-51

Ozden A, Dios-Palomares R (2016) Is the olive oil an efficient sector? A meta frontier analysis considering the ownership structure. New Medit 15[3]: 2-9

Pires IM, Neves B (2013) From periphery to Euroregion: Foreign investment in olive groves in an Alentejo in times of change. Place-based policies and economic recovery. Universidade do Minho, Braga, Portugal

Roig A, Cayuela ML, Sánchez-Monedero MA (2006) An overview on olive mill wastes and their valorisation methods. Waste Management 26[9]: 960-969. CrossRef.

Rossi R (2017) The EU olive and olive oil sector. Main features, challenges and prospects. Members' research service no. PE 608.690, p. 12. European Parliamentary Research Service, European Parliament

Salomone R, Ioppolo G (2012) Environmental impacts of olive oil production: A life cycle assessment case study in the province of Messina (Sicily). Working towards a more sustainable agri-food industry: Main findings from the Food LCA 2010 conference in Bari, Italy, 28, 88-100

Scheidel A, Krausmann F (2011) Diet, trade and land use: A socio-ecological analysis of the transformation of the olive oil system. Land Use Policy 28: 47-56. CrossRef.

Stoate C, Báldi A, Beja P, Boatman ND, Herzon I, van Doorn A, de Snoo GR, Rakosy L, Ramwell C (2009) Ecological impacts of early 21st century agricultural change in Europe - A review. Journal of Environmental Management 91[1]: 22-46. CrossRef.

Stroosnijder L, Mansinho MI, Palese AM (2008) OLIVERO: The project analysing the future of olive production systems on sloping land in the Mediterranean basin. $A$ Sustainable Future for Olive Production on Sloping Land 89[2]: 75-85

Türkekul B, Günden C, Abay C, Miran B (2010) Competitiveness of Mediterranean countries in the olive oil market. New Medit 9[1]: 41-46

UNESCO - United Nations Educational, Scientific and Cultural Organization (2013a) Decisions. UNESCO, Baku, Azerbaijan

UNESCO - United Nations Educational, Scientific and Cultural Organization (2013b) Nomination file no. 00884 for inscription in 2013 on the Representative List of the Intangible Cultural Heritage of Humanity. UNESCO, Baku, Azerbaijan

Vanwalleghem T, Laguna A, Giráldez JV, Jiménez-Hornero FJ (2010) Applying a simple methodology to assess historical soil erosion in olive orchards. Geomorphology 114[3]: 294-302. CrossRef.

Weissteiner C, Strobl P, Sommer S (2011) Assessment of status and trends of olive farming intensity in U-Mediterranean countries using remote sensing time series and land cover data. Ecological Indicators 11[2]: 601-610. CrossRef.

c) (F) () (c) 2018 by the authors. Licensee: REGION - The Journal of ERSA, European Regional Science Association, Louvain-la-Neuve, Belgium. This article is distributed under the terms and conditions of the Creative Commons Attribution, Non-Commercial (CC BY NC) license (http://creativecommons.org/licenses/by-nc/4.0/). 